\title{
ERGONOMI DALAM PEMBELAJARAN MENUNJANG PROFESIONALISME GURU DI ERA GLOBAL
}

\author{
Pande Wayan Mustika' ${ }^{1}$ I Made Sutajaya ${ }^{2}$ \\ ${ }^{1}$ Guru SMP Negeri 3 Tegallalang Gianyar, Indonesia \\ 2Jurusan Pendidikan Biologi, Universitas Pendidikan Ganesha, Indonesia \\ E-mail: pandemustika@yahoo.co.id
}

\begin{abstract}
Abstrak
Di era global persaingan semakin keras dan ketat yang disertai dengan munculnya permasalahan yang semakin kompleks. Hal yang sama juga terjadi pada proses pembelajaran, sehingga profesionalisme guru perlu ditingkatkan. Salah satu cara yang dapat ditempuh adalah melalui pemahaman terhadap prinsip-prinsip ergonomi dalam pembelajaran. Tujuan penulisan adalah: (1) mengkaji pemahaman terhadap prinsip-prinsip ergonomi dalam pembelajaran sangat diperlukan di dalam upaya meningkatkan profesionalisme guru; (2) mengkaji peranan prinsip-prinsip ergonomi dalam pembelajaran yang harus dipahami oleh seorang guru untuk meningkatkan profesionalismenya; dan (3) mengetahui kendala yang dihadapi dalam mensosialisasikan prinsip-prinsip ergonomi dalam pembelajaran guna meningkatkan profesionalisme guru. Melalui telaah kajian pustaka ditelusuri prinsip-prinsip ergonomi yang relevan diterapkan dalam pembelajaran. Hasil kajian menunjukkan bahwa para guru saat ini belum memahami prinsip-prinsip ergonomi yang relevan dalam pembelajaran. Akan tetapi melalui tulisan ini diingatkan agar para guru wajib menerapkan prinsip-prinsip ergonomi dalam pembelajaran agar siswa yang belajar tetap sehat, aman, nyaman, efektif, dan efisien energi. Dengan demikian dapat disimpulkan: (1) pengetahuan guru mengenai prinsip-prinsip ergonomi dalam pembelajaran sangat relevan di dalam upaya meningkatkan profesionalisme guru; (2) pemahaman guru mengenai peranan prinsip-prinsip ergonomi dalam pembelajaran dan dampak yang ditimbulkan oleh sarana dan prasarana yang tidak ergonomik dapat menambah wawasannya dalam upaya pengelolaan kelas; dan (3) kendala yang dihadapi dalam mensosialisasikan prinsip-prinsip ergonomi dalam pembelajaran dapat dijadikan tantangan sekaligus peluang dalam penerapan ergonomi di sekolah.
\end{abstract}

Kata-kata kunci: ergonomi, pembelajaran, dan profesionalisme guru

\begin{abstract}
In globalization, competition is getting harder and tighter, accompanied by the emergence of increasingly complex problems. The same thing happened in the teaching and learning process, so that the professionalism of teachers needs to be improved. One way that can be achieved is through the understanding of the principles of ergonomics in teaching and learning. The purposes of writing are: (1) assess the understanding of the principles of ergonomics in teaching and learning
\end{abstract}


is required in an effort to improve the professionalism of teachers; (2) examine the role of ergonomic principles of teaching and learning that must be understood by a teacher to improve professionalism; and (3) determine the obstacles encountered in disseminating the principles of ergonomics in order to improve the professionalism of teachers in teaching and learning. Through literature review study traced ergonomic principles applied in the teaching and learning. The results showed that teachers now have not understood the principles of ergonomics that are relevant for teaching and learning. However, through this paper are reminded that teachers are required to apply the principles of ergonomics in teaching and learning so that students learn to stay healthy, safe, convenient, effective, and efficient of energy. It can be concluded: (1) knowledge of teachers on the principles of ergonomics in teaching and learning is very relevant in the effort to improve the professionalism of teachers; (2) teachers' understanding of the role of ergonomic principles in teaching and learning and the impact caused by facilities and infrastructure are not ergonomic can add insights in classroom management efforts; and (3) the constraints faced in disseminating the principles of ergonomics in teaching and learning can be a challenge and an opportunity in the application of ergonomics in school.

Keywords: ergonomics, teaching and learning, and professionalism of teachers

\section{PENDAHULUAN}

Di era global persaingan semakin keras dan ketat yang disertai dengan munculnya permasalahan yang semakin kompleks, khususnya dalam pembelajaran menuntut profesionalisme guru yang semakin meningkat. Untuk menyiasati kompetisi yang semakin ketat dan kompleksnya permasalahan mengharuskan seorang guru mau, mampu, dan berani berubah. Untuk itu diperlukan upaya peningkatan profesionalisme khususnya yang berkaitan dengan pemahaman terhadap prinsip-prinsip ergonomi yang dapat diterapkan dalam proses pembelajaran. Ergonomi adalah ilmu, teknologi, dan seni untuk menserasikan alat, cara kerja dan lingkungan pada kemampuan, kebolehan dan batasan manusia, sehingga diperoleh kondisi kerja dan lingkungan yang sehat, aman, nyaman, efektif dan efisien demi tercapainya produktivitas yang setinggi-tingginya (Manuaba, 2004a). Ruang belajar yang ergonomis tentunya akan membuat seseorang merasa nyaman di dalam melakukan aktivitasnya di ruang tersebut.

Salah satu prinsip dasar ergonomi dalam perancangan adalah human-centered design. Maksudnya adalah suatu rancangan hendaknya memperhatikan factor manusia sebagai pengguna yang mempunyai berbagai keterbatasan secara individu dan juga memiliki variasi antar individu (Iridiastadi, 2014). Selain itu ergonomi adalah ilmu yang dalam penerapannya berusaha agar manusia bisa selaras dengan pekerjaan dan lingkungan sehingga proses perancangan juga harus sesuai dengan ukuran tubuh manusia yang menggunakannya (Wignjosoebroto, 2000).

Akan tetapi saat ini tampaknya kaidah-kaidah ergonomi belum diterapkan dalam mendesain ruang belajar dengan perangkat pendukungnya, baik di sekolah-sekolah 
maupun di tempat-tempat pendidikan lainnya yang disinyalir diakibatkan oleh kurangnnya pengetahuan guru terhadap prinsip-prinsip ergonomi yang dapat diterapkan dalam proses pembelajaran. Misalnya; penempatan papan tulis, pemakaian lampu penerang, pembuatan tulisan di papan tulis, penampilan tulisan pada layar overhead projector, ukuran tempat duduk dan meja belajar nampaknya belum memenuhi syaratsyarat ergonomi. Ditinjau dari faktor lingkungan tempat belajar, tampaknya belum diperhatikan mengenai mikroklimat di ruang belajar.

Padahal beberapa laporan penelitian melaporkan bahwa penerapan ergonomi di ruang belajar dapat meningkatkan hasil belajar. Dalam hal ini Sutajaya (2001) melaporkan bahwa penerapan ergonomik partisipatori yang salah satunya adalah mengubah kondisi statis menjadi dinamis pada proses pembelajaran anatomi fisiologi manusia dapat meningkatkan hasil belajar mahasiswa dari rerata nilai 6,5 menjadi 7,0. Sutjana, Sutajaya, Tunas, \& Suardana (2004) melaporkan bahwa hasil belajar mahasiswa meningkat dari rerata nilai 58,71 pada siklus I menjadi 62,06 pada siklus II atau meningkat sebesar 5,70\% $(p<0,05)$ setelah diterapkan pembelajaran yang mengacu aspek ergonomi.

\section{Ergonomi}

sesungguhnya

berusaha untuk mengupayakan agar ruang belajar menjadi nyaman untuk dimanfaatkan sebagai tempat belajar, sehingga energi sepenuhnya dapat dimanfaatkan untuk kegiatan belajar saja dan tidak terbuang percuma karena harus menghadapi kondisi lingkungan belajar yang tidak ergonomis. Untuk mengatasi hal tersebut, perlu dikaji mengenai kaidah-kaidah ergonomi yang dapat dimanfaatkan di dalam mendesain ruang belajar sebagai upaya untuk meningkatkan profesionalisme guru dalam proses pengelolaan kelas. Dalam hal ini, Gamez \& Cybis (1998) menyatakan bahwa sarana pembelajaran sangat menentukan kualitas proses pembelajaran yang pada akhirnya akan meningkatkan prestasi belajar.

Bertolak dari latar belakang masalah di atas dapat dibuat rumusan masalah: (1) mengapa pemahaman terhadap prinsip-prinsip ergonomi dalam pembelajaran sangat diperlukan di dalam upaya meningkatkan profesionalisme guru?; (2) bagimanakah peranan prinsip-prinsip ergonomi dalam pembelajaran yang harus dipahami oleh seorang guru untuk meningkatkan profesionalismenya?; dan (3) apakah kendala yang dihadapi dalam mensosialisasikan prinsip-prinsip ergonomi dalam pembelajaran guna meningkatkan peofesionalisme guru?

\section{METODE}

Penelitian deskriptif ini mengacu kepada beberapa literatur yang relevan dan dikaji berdasarkan acuan-acuan terkini yang dikaitkan dengan upaya peningkatan profesionalisme guru. Dalam hal ini dibahas mengenai kadahkaidah ergonomi yang perlu dipahami oleh seorang guru sebagai suatu pengetahuan yang akan diaplikasikan dalam pembelajaran. Kajian literatur ini lebih difokuskan pada upaya eksplorasi pengetahuan yang relevan dan efektif serta efisien untuk diterapkan di sekolah maupun di tempat-tempat pembelajaran lainnya. 
Metode yang digunakan adalah kajian pustaka yang diperoleh melalui berbagai sumber. Argumentasi penulis diarahkan kepada upaya memadukan pengalaman pembelajaran yang digeluti penulis selama ini dan disinkronkan dengan teori yang ada. Berbagai kendala di lapangan yang sering dijumpai penulis dalam pembelajaran berusaha dicarikan alternatif solusinya melalui kajian ini.

\section{HASIL DAN PEMBAHASAN}

Ergonomi berasal dari kata Yunani yaitu ergon (kerja) dan nomos (aturan). Definisi ergonomi adalah ilmu, teknologi dan seni untuk menyerasikan alat, cara kerja dan lingkungan pada kemampuan, kebolehan dan batasan manusia sehingga diperoleh kondisi kerja dan lingkungan yang sehat, aman, nyaman dan efisien sehingga tercapai produktivitas yang setinggi-tingginya (Manuaba, 2003a). Ergonomi sangat diperlukan di dalam suatu kegiatan yang melibatkan manusia di dalamnya dengan memperhitungkan kemampuan dan tuntutan tugas.

Kemampuan manusia sangat ditentukan oleh faktor-faktor profil, kapasitas fisiologi, kapasitas psikologi dan kapasitas biomekanik, sedangkan tuntutan tugas dipengaruhi oleh karakteristik dari materi pekerjaan, tugas yang harus dilakukan, organisasi dan lingkungan dimana pekerjaan itu dilakukan (Manuaba, 2003a). Dengan ergonomi dapat ditekan dampak negatif pemanfaatan ilmu pengetahuan dan teknologi, karena dengan ergonomi berbagai penyakit akibat kerja, kecelakaan, pencemaran, keracunan, ketidak-puasan kerja, kesalahan unsur manusia, bisa dihindari atau ditekan sekecil-kecilnya (Manuaba, 2003a).

Pemanfaatan

prinsip-prinsip ergonomi dalam mendesain suatu produk membuat produk tersebut menjadi lebih sesuai dengan pemakai (users friendly), memuaskan, nyaman dan aman (Velasco, 2002). Untuk memudahkan dan mengurangi dampak negatif yang mungkin timbul, penerapan ergonomi hendaknya menggunakan bahasa yang sederhana, bahasa perusahaan atau bahasa masyarakat. Pendekatan sistemik, holistik, interdisipliner dan partisipatori (SHIP) hendaknya selalu dimanfaatkan dalam setiap pemecahan masalah atau merencanakan sesuatu sehingga tidak ada lagi masalah yang tertinggal atau muncul di kemudian hari (Manuaba, 2004b). Di samping itu pendekatan SHIP hendaknya diterapkan dalam pemilihan dan alih teknologi sehingga menjadi tepat guna, dengan persyaratan: (a) secara teknik hasilnya lebih baik; (b) secara ekonomi lebih menguntungkan; (c) secara sosial budaya dapat diterima; (d) kesehatan dapat dijamin dan dipertanggungjawabkan; (e) hemat dalam pemakaian energi; dan (f) tidak merusak lingkungan (Manuaba, 2003b, 2004a).

Dari beberapa perbaikan ergonomi yang telah dilakukan oleh para ahli di luar negeri yang pencatatan datanya sudah baik, rapi dan teratur, terbukti bahwa dengan penerapan ergonomi mampu memberikan keuntungan secara ekonomi, meningkatkan keselamatan dan kenyamanan kerja. Malah telah sampai pada simpulan Good ergonomic is good economic. Maksudnya adalah, apabila ergonomi dapat diterapkan 
dengan baik dan benar akan dapat memberikan keuntungan ekonomi yang lebih baik. Ini bisa diterima dan dipertanggung-jawabkan, karena hasil yang dicapai melalui penerapan ergonomi yang baik dan benar memberikan manfaat: (a) pemakaian tenaga otot bisa lebih efisien; (b) pemanfaatan waktu lebih efisien; (c) kelelahan berkurang; (d) kecelakaan kerja berkurang atau dapat ditiadakan; (e) penyakit akibat kerja berkurang; (f) kenyamanan dan kepuasan kerja meningkat; (g) efisiensi kerja meningkat; (h) mutu produk dan produktivitas kerja meningkat; (i) kesalahan kerja berkurang dan kerusakan dapat diminimalka; dan (j) pengeluaran untuk mengatasi akibat dari kecelakaan dan penyakit akibat kerja dapat dikurangi yang konsekuensinya biaya operasional dapat ditekan (Manuaba, 2000 c).

Makroergonomik secara formal diakui sebagai sub disiplin ilmu dalam dua dekade terakhir ini (Hendrick, 2002b). Aspek-aspek sosial yang digunakan untuk mendeterminasi implikasi dari pertumbuhan, perkembangan dan keefektifan dari human factors discipline atau ergonomi adalah: (1) melakukan terobosan dalam teknologi untuk melakukan perubahan secara fundamental terhadap natural of work; (2) menentukan kemampuan kerja yang berhubungan dengan tingkat pendidikan, pengalaman dan kematangan atau kedewasaan seseorang; (3) memberikan nilai perbedaaan yang mendasar setelah perang dunia II dilihat dari beberapa fakta yang ada berupa partisipasi dalam membuat kebijakan, adanya kemampuan berbicara, adanya kepuasan sosial yang berhubungan dengan pekerjaan; (4) mengatasi ketidakmampuan dan lemahnya treatment dalam mikroergonomik untuk mengurangi kehilangan waktu kerja yang diakibatkan oleh kecelakaan dan penyakit akibat kerja dan meningkatkan produktivitas; dan (5) meningkatkan kondisi di tempat kerja dan legitimasi suatu produk berdasarkan desain ergonomi yang aman (Hendrick, 2002b).

Biasanya guru dan siswa kurang menghiraukan tempat duduk yang mereka duduki. Padahal tempat duduk tersebut merupakan alat yang memegang peranan penting, terutama bagi mereka yang melakukan aktivitas sambil duduk seperti yang dilakukan oleh para siswa di sekolah. Sebuah tempat duduk (kursi) yang lengkap, minimal harus mempunyai kaki, alas duduk, sandaran pinggang dan punggung dan sandaran lengan (Nala, 1994).

Agar tempat duduk nyaman dipakai pada waktu belajar, maka ukuran-ukurannya harus disesuaikan dengan antropometri orang yang akan memakainya. Dalam hal ini diperlukan pembakuan terhadap ukuran-ukuran tubuh (antropometri) orang-orang Indonesia pada umumnya atau orangorang Bali pada khususnya, sehingga dalam mendesain tempat duduk (kursi) dapat mengacu kepada ukuran-ukuran tersebut. Seandainya ukuran-ukuran baku tersebut belum ada, dapat dilakukan pengukuran terhadap antropometri siswa atau mahasiswa yang akan menggunakan tempat duduk tersebut. Tapi jika data antropometri siswa tersebut juga tidak ada, maka dapat digunakan persyaratan tempat duduk sebagai berikut (Nala, 1994). 
1. Tinggi alas duduk dari lantai $38-54$ $\mathrm{cm}$ (setinggi telapak kaki sampai belakang lutut atau popliteal).

2. Alas duduk hendaknya agak miring ke belakang $\left(14^{\circ}-24^{\circ}\right.$ dari bidang horizontal atau dari lantai). Kemiringan ini diperlukan, agar tubuh tidak melorot ke depan pada saat duduk

3. Ujung tepi depan alas duduk dibuat agak bulat untuk menghindari tekanan pada bagian bawah paha. Ujung bagian depan ini dapat ditinggikan $4^{\circ}-6^{\circ}$ dari alas duduk.

4. Luas alas duduk sebaiknya disesuaikan dengan ukuran pantat yaitu: 40 - $45 \mathrm{~cm}$ melintang dan $38-$ $42 \mathrm{~cm}$ membujur.

5. Sandaran pinggang dan punggung hendaknya agak miring ke belakang dengan sudut $105^{\circ}-110^{\circ}$ terhadap alas duduk. Bentuk sandaran pinggang dan punggung sebaiknya disesuaikan dengan lengkung vertebrae pada tubuh manusia. Sandaran tersebut akan menopang punggung dan pinggang dengan baik bila ukuran tingginya $48-50 \mathrm{~cm}$ dan lebarnya $32-36 \mathrm{~cm}$.

Pengetahuan

tersebut

memegang peranan penting di dalam meningkatkan pemahaman guru tentang kaidah yang harus diikuti terkait dengan tempat duduk siswa.

Meja belajar adalah meja yang digunakan sebagai alas pada saat melakukan aktivitas belajar. Bila meja belajar terlalu tinggi maka bahu akan lebih sering terangkat pada saat menulis atau meletakkan tangan di atas meja dan bila terlalu rendah maka sikap tubuh akan membungkuk pada saat menulis. Sikap tubuh yang seperti itu dapat mengakibatkan sakit pinggang atau punggung dan sakit pada otot-otot leher dan bahu. Terkait dengan masalah tersebut, Sutajaya \& Citrawathi (2001) melaporkan bahwa perbaikan kondisi kerja yang mengacu kepada kaidahkaidah ergonomi dalam menggunakan mikroskop di Laboratorium Biologi STKIP Singaraja mengurangi gangguan pada sistem muskuloskeletal sebesar $54,03 \%(p<0,05)$. Untuk mengatasi masalah tersebut maka perlu dipilih meja belajar yang sesuai dengan si pemakainya. Dalam hal ini, Grandjean (1988) menyatakan bahwa tinggi meja untuk menulis dan membaca dalam posisi duduk adalah antara $74-78 \mathrm{~cm}$ untuk laki-laki dan antara $70-74 \mathrm{~cm}$ untuk wanita. Sedangkan Dul \& Weerdmeester (2003) menyatakan bahwa untuk kegiatan yang sering menggunakan mata, tangan dan lengan sebaiknya bidang kerja berada pada 0 $15 \mathrm{~cm}$ di atas tinggi siku. Pengetahuan ini memegang peranan penting di dalam upaya peningkatakan pemahaman guru tentang manfaat meja belajar yang ergonomic bagi kesehatan dan kenyamanan siswa dalam proses pembelajaran.

Papan tulis yang digunakan sebagai sarana belajar, kadang-kadang ditempatkan pada tempat yang tidak ergonomis, sehingga dapat memunculkan gangguan fisiologis pada siswa atau mahasiswa saat membaca tulisan atau pesan yang dibuat di papan tulis tersebut. Untuk mengatasi masalah tersebut perlu diketahui kaidah-kaidah ergonomi yang dapat digunakan sebagai acuan di dalam penempatan papan tulis tersebut. Dalam hal ini Grandjean (1988) menganjurkan agar rotasi mata saat melihat suatu objek, tidak lebih dari $5^{\circ}$ di atas horizontal 
plane dan $30^{\circ}$ di bawah horizontal plane. Dengan demikian berarti penempatan papan tulis hendaknya memperhitungkan siswa yang duduk paling depan dan paling belakang, sehingga rotasi mata mereka tetap berada pada rentangan tersebut di atas. Dengan kata lain, tinggi papan tulis harus mengacu kepada tinggi mata siswa dalam posisi duduk.

Di samping itu masalah silau juga harus diperhitungkan, karena silau membuat rasa tidak nyaman dan mengurangi kemampuan mata untuk melihat. Silau muncul karena ada bagian-bagian lapang pandang yang terlalu terang dibandingkan dengan tingkat penerangan umum di tempat tersebut. Silau dapat dihindari dengan jalan: (1) menempatkan dengan tepat sumber penerangan terhadap tempat kerja atau sebaliknya; (2) menurunkan intensitas penerangan sumber; (3) mengganti bahan yang mengkilat; (4) memberi penerangan yang memadai pada latar belakang penyebab silau tersebut; dan (5) menghilangkan kontras (Manuaba, 2004a). Pemahaman guru terhadap kajian ergonomi dalam penempatan papan tulis dan faktor silau yang dapat mengganggu proses pembelajaran dapat dimanfaatkan sebagai upaya peningkatan profesionalisme guru dalam mengelola sarana pembelajaran.

Penerangan yang baik sangat penting, agar pekerjaan dapat dilakukan dengan benar dan dalam situasi nyaman. Di samping itu pada saat melakukan aktivitas dapat melihat objek dengan jelas dan cepat, sehingga tidak melelahkan mata. Prinsip penerangan yang baik adalah: (1) jumlah atau intensitas penerangan yang diperlukan hendaknya disesuaikan dengan jenis pekerjaan, tajam lihat seseorang dan lingkungannya; (2) diupayakan agar mendapatkan penampilan penglihatan sebesar 100\%; (3) di dalam merencanakan penerangan, di samping efisiensi penglihatan, faktor keamanan, kenyamanan dan keselamatan perlu diperhitungkan; (4) intensitas penerangan yang baik adalah minimal 200 lux, atau disesuaikan dengan jenis aktivitas di tempat tersebut; dan (5) penerangan harus diutamakan pada pekerjaan pokok, kemudian pada latar belakangnya dan terakhir pada lingkungannya (dinding, atap, lantai dan lain-lain) (Manuaba, 2004a).

Untuk kegiatan belajar (membaca dan menulis) diperlukan intensitas penerangan sebesar 350 700 lux (Grandjean, 1988). Data ini ditunjang oleh hasil temuan Antari (2004) yang melaporkan bahwa intensitas pencahayaan di ruang mikro konseling IKIP Singaraja adalah 398,75 lux pada kelompok perlakuan dan 402,56 lux pada kelompok kontrol. Untuk memperoleh penerangan sebesar 600 lux, berapa diperlukan lampu TL "b" watt dalam ruangan seluas " $a$ " $\mathrm{m}^{2}$, dapat dilihat pada rumus sebagai berikut (Manuaba, 2004a).

$$
X=(a \times 60 \times 1 / 15 \text { watt }): b
$$

Contoh:

Berapakah diperlukan lampu TL 40 watt dalam ruangan seluas $100 \mathrm{~m}^{2}$

$X=(100 \times 60 \times 1 / 15$ watt $): 40$ watt

$=(6000 / 15$ watt $): 40$ watt

$=400: 40$

$=10$

Jadi diperlukan 10 lampu TL

Dalam hal ini penggunaan lampu

neon (TL) lebih baik daripada lampu

pijar, karena lampu TL memberi 
penerangan sebesar $75 \%$ dan panas hanya 25\%. Sedangkan lampu pijar mengeluarkan panas $75 \%$ dan memberi penerangan hanya $25 \%$. Di samping kelebihan tersebut, lampu TL juga memiliki kekurangan yaitu: adanya efek getaran. Masalah ini dapat diatasi dengan jalan menutup ujung-ujung lampu TL, jika digunakan hanya satu lampu, tapi jika digunakan lebih dari satu lampu TL, hendaknya dipasang dengan $\mathrm{T}$ sistem.

Jika menggunakan penerangan alami, hendaknya memperhatikan luas jendela 1/5 x luas lantai dan diupayakan agar lantai dan plafon berwarna lembut atau putih untuk membantu refleksi sinar dan untuk mengurangi kontras. Dengan demikian dapat dikatakan bahwa penerangan di ruang belajar dapat diupayakan dengan menyesuaikan intensitas penerangan dengan jenis kegiatan yang dilakukan di ruang belajar. Hal ini akan sangat membantu untuk mengatasi kelelahan mata yang diakibatkan oleh intensitas penerangan yang tidak memadai. Olszewski (1998) melaporkan bahwa penerangan yang tidak cukup pada tempat kerja operator komputer mengakibatkan 77,8\% operator mengeluh sakit mata. Jika hal ini terjadi pada ruang belajar, tentu akan mengganggu proses pembelajaran yang pada akhirnya akan menurunkan prestasi pebelajar. Di samping itu Partadjaja (2004) melaporkan bahwa perbaikan sistem pencahayaan dan media pembelajaran meningkatkan kecepatan kerja siswa sebesar $70,46 \%$, ketelitian sebesar $56,36 \%$ dan konstansi kerja sebesar 90,95\%. Pengetahuan ini dapat diaplikasikan oleh seorang guru ketika ingin mendapatkan penerangan yang memadai dalam proses pembelajaran dan ketika mereka menentukan pilihan terhadap jenis sumber penerangan yang cocok untuk proses pembelajaran.

Ketika digunakan power point dalam pembelajaran untuk menampilkan informasi yang ingin disampaikan ke anak didik, kadang-kadang tidak diperhatikan seberapa besar huruf yang digunakan dan berapa baris kalimat yang seharusnya ditulis pada satu slide. Ketidak-pedulian terhadap hal itu mengakibatkan tampilan tulisan-tulisan di layar yang tidak terbaca oleh pebelajar yang duduk paling belakang. Masalah ini sering muncul, karena belum diperhatikannya kaidah-kaidah ergonomi, sehingga dapat mengakibatkan respon fisiologis yang tidak menguntungkan, seperti misalnya terjadi akomodasi mata yang tidak alamiah yang sudah tentu akan mempercepat munculnya kelelahan pada mata (Grandjean, 1988). Pendapat ini didukung oleh Gamez \& Cybis (1998)yang menyatakan bahwa sarana pembelajaran yang tidak memenuhi syarat ergonomi mengakibatkan atau merusak kualitas pembelajaran yang berkaitan dengan tujuan yang ingin dicapai.

Untuk mengatasi masalah tersebut di atas, dalam hal ini perlu dikaji tentang kaidah-kaidah ergonomi yang dapat diterapkan dalam pemakaian huruf tersebut dengan ketentuan sebagai berikut (Manuaba, 1998).

Tinggi huruf (dalam $\mathrm{mm})=$ jarak baca (dalam mm)/200

Lebar huruf $=2 / 3 \times$ tinggi huruf

Tebal huruf $=1 / 6 \times$ tinggi huruf

Jarak antara 2 huruf $=1 / 5 x$ tinggi huruf Jarak antara 2 kata $=2 / 3 \times$ tinggi huruf 
Jarak antara 2 baris kalimat $=1 \times$ tinggi huruf

Dalam hal ini huruf yang gelap di atas latar belakang (background) yang terang lebih ergonomis dibandingkan dengan huruf yang terang di atas latar belakang yang gelap jika tidak ada efek pantulan cahaya, seperti tulisan pada white board. Akan tetapi jika latar belakangnya berwarna hijau tua atau biru tua maka tulisan sebaiknya berwarna terang (putih) karena ada efek cahaya yang keluar dari LCD dan dipantulkan di layar (screen). Jika latar belakang berwarna putih maka tulisan sebaiknya berwarna hitam atau biru tua.
Hindari penggunaan warna merah atau ungu untuk latar belakang atau tulisan yang ingin ditampilan dalam power point karena warna merah memiliki efek psikofisiologis yang sifatnya mengganggu dan warna ungu bersifat agresif sehingga dapat menimbulkan keluhan seperti: (a) sakit kepala; (b) sakit di sekitar mata; (c) nek di sekitar mata; (d) mata berair; (e) mata perih; (f) penglihatan kabur; (g) penglihatan ganda; dan (h) mata lelah (frekuensi kedipan mata meningkat) (Sutajaya, 2009b). Di samping itu perlu dipertimbangkan penggunaan warna lainnya karena memiliki sifat seperti yang tertera pada Tabel 1.

Tabel 1 Efek Psikofisiologis Warna

\begin{tabular}{cccc}
\hline Warna & Efek jarak & Efek Suhu & Efek Psikofisiologis \\
\hline Biru & jauh & dingin & lembut \\
Hijau & jauh & sangat dingin & sangat lembut \\
Merah & dekat & hangat/panas & mengganggu \\
Oranye & sangat dekat & sangat panas & merangsang \\
Kuning & dekat & sangat panas & merangsang \\
Coklat & sangat dekat & netral & merangsang \\
Ungu & sangat dekat & dingin & agresif \\
\hline
\end{tabular}

Animasi suara dalam e-learning hendaknya memperhatikan intensitas kebisingannya. Karena intensitas bising yang tidak adekuat dapat menimbulkan berbagai masalah fisiologis dalam tubuh seperti: (a) auditory effect yaitu pengaruh bising terhadap organ pendengaran sehingga dapat berakibat terjadi tuli temporer atau tuli permanent dan (b) non auditory effect yaitu: (1) tekanan darah meningkat; (2) sistem kardiovaskuler atau denyut nadi/ denyut jantung meningkat; (3) terjadi gangguan organ pencernaan; (4) terjadi gangguan pada sistem urinaria (poliurea); (5) tonus otot meningkat sehingga terjadi keluhan muskuloskeletral; dan (6) berpengaruh terhadap fakor psikologis berupa insomnia/sukar tidur, susah konsentrasi, ketenangan terganggu, dan gelisah.

Sebagai acuan dalam menentukan animasi suara yang ingin diaplikasikan dalam e-learning dapat dilihat ketentuan bising pada Tabel 2 . 
Tabel 2 Intensitas Bising sesuai Pekerjaan

\begin{tabular}{clc}
\hline No & \multicolumn{1}{c}{ Tipe Pekerjaan } & $\begin{array}{c}\text { Nilai Ambang Batas (NAB) } \\
\text { Bising (dB(A)) }\end{array}$ \\
\hline 1 & Pekerjaan fisik non keahlian & 80 \\
2 & Kerja fisik dengan sedikit keahlian & 75 \\
3 & Kerja fisik dengan ketelitian & 70 \\
4 & Kerja administrasi rutin & 70 \\
5 & Kerja administrasi dengan ketelitian tinggi & 60 \\
6 & Kerja administrasi + komunikasi & 55 \\
7 & Kerja mental dengan konsentrasi tinggi & 45 \\
8 & Baca di perpustakaan & 35 \\
\hline
\end{tabular}

Animasi musik dalam e-learning juga sering dimanfaatkan dalam pembelajaran. Dalam hal ini, Pasiak \& Others (2007) menyatakan bahwa alunan musik memberikan nuansa pada jiwa yang mampu membawa perubahan. Beberapa penelitian mengungkapkan bahwa musik tertentu dapat memperbaiki kekebalan tubuh, meningkatkan vitalitas, dan meningkatkan kegembiraan atau keriangan hati sepanjang hari. Tubuh banyak merekam berbagai hal yang memberi nuansa pada jiwa. Misalnya ketika menghadapi ujian atau materi pembelajaran yang agak berat, akan muncul respon fisiologis berupa: (a) denyut nadi atau denyut jantung meningkat; (b) frekuensi pernafasan bertambah cepat; (c) pengeluaran keringat bertambah; (c) vasokontriksi pembuluh darah; (d) aliran darah bertambah cepat; (e) pupil mata melebar; dan (f) tubuh semakin lemas. Di sini diperlukan musik yang tepat yang diterapkan dalam e-learning dengan memperhatikan ketentuan pada Tabel 3.

Tabel 3 Elemen Musik yang Dikaitkan dengan Mood tertentu

\begin{tabular}{llll}
\hline \multirow{2}{*}{ Elemen } & \multicolumn{2}{c}{ Kegembiraan } & \multicolumn{1}{c}{ Kesedihan } \\
\cline { 2 - 4 } & Tinggi & Rendah & \multicolumn{1}{c}{ Kegairahan } \\
\hline Frekuensi & Kuat & Tajam & Kuariasi \\
Variasi melodi & Mula-mula moderat, & Menurun & Mula-mula kuat lalu \\
Tone course & lalu menurun & & menurun \\
& Many overtones & Fewer overtones & Barely any overtones \\
Warna nada & Cepat & Lambat & Medium \\
Tempo & Keras & Halus & Variasi tinggi \\
Volume & Tak teratur & Teratur & Variasi tak teratur \\
Ritme & \multicolumn{2}{c}{ (Sumber: Howard, 2006 dalam Pasiak \& Others, 2007) } \\
\hline
\end{tabular}

Mikroklimat di ruang belajar ditentukan oleh suhu udara, suhu permukaan (suhu di atas meja, jendela, dinding, lantai dan lain-lain), kelembaban udara, gerakan udara dan kualitas udara. Suhu yang dirasakan 
seseorang merupakan rerata dari suhu udara dan suhu permukaan. Untuk rasa nyaman, perbedaan suhu udara dan suhu permukaan hendaknya sekecil mungkin, karena itu diambil patokan agar perbedaan rerata suhu permukaan hendaknya tidak lebih dari $2-3^{\circ} \mathrm{C}$ di atas atau di bawah suhu udara. Sedangkan perbedaan suhu antara di dalam dengan di luar ruangan, tidak lebih dari $4^{\circ} \mathrm{C}$. Jika melebihi batas tersebut, hendaknya dibuat ruang antara untuk proses adaptasi terhadap perbedaan suhu tersebut (Manuaba, 2004a).

Suhu udara di satu ruangan, hendaknya antara $20-24^{\circ} \mathrm{C}$ pada musim dingin dan antara $23-26^{\circ} \mathrm{C}$ di musim panas (Helander \& Shuan, 2005). Sedangkan kelembaban relatif di satu ruangan tidak boleh kurang dari $30 \%$ atau antara $40-60 \%$ di musim panas, merupakan kelembaban relatif yang memberi suasana nyaman di ruangan tersebut. Suhu nyaman untuk daerah tropis adalah antara 22 s.d. $28^{\circ}$ $\mathrm{C}$ dengan kelembaban relatif antara 70 s.d. $80 \%$ (Manuaba, 2004a). Gerakan udara di satu ruangan memberi pengaruh kepada suhu yang dirasakan seseorang. Agar gerakan udara tersebut tidak menimbulkan dampak yang tidak diinginkan, maka dalam hal ini dianjurkan agar gerakan udara di dalam ruangan tidak lebih dari $0,2 \mathrm{~m} /$ detik (Manuaba, 2004a).

Seandainya mikroklimat di ruang belajar tidak diperhatikan, sehingga ruang tersebut menjadi panas, maka akan menimbulkan respon fisiologis: (a) meningkatnya rasa lelah yang diikuti dengan hilangnya efisiensi kerja mental dan fisik; (b) denyut jantung meningkat; (c) tekanan darah meningkat; (d) aktivitas alat pencernaan menurun; (e) suhu inti tubuh meningkat; (f) aliran darah ke kulit juga meningkat; dan (g) produksi keringat meningkat. Melihat dampak negatif yang ditimbulkan oleh suhu ruangan yang panas, maka sudah menjadi keharusan bagi untuk mendisain ruang belajar yang mengacu kepada kaidah-kaidah ergonomi, demi tercapainya produktivitas belajar yang setinggi-tingginya. Dengan demikian berarti energi yang dikeluarkan sepenuhnya untuk kegiatan belajar dan tidak ada energi yang terbuang untuk mengatasi kondisi ruangan yang tidak nyaman. Pengetahuan guru tentang mikroklimat di ruang belajar dapat dimanfaatkan sebagai acuan di dalam mendesain ruang belajar yang nyaman dan tidak menimbulkan respon fisiologis yang tidak diinginkan.

Pembelajaran

melalui pendekatan SHIP menghendaki pergeseran peran mahasiswa yang semula hanya bertindak sebagai penerima informasi secara pasif menjadi: (a) pebelajar yang aktif dan inovatif; (b) pebelajar yang mampu berpikir kritis dan kreatif dalam menganalisis dan mengaplikasikan fakta, konsep dan prinsip yang dipelajari; (c) pebelajar yang mampu bekerja dalam tim secara kondusif; (d) pebelajar yang mampu mengkaji masalah secara sistemik, holistik dan interdisipliner; dan (e) pebelajar yang peka terhadap masalah yang ada di masyarakat yang ditelusuri secara partisipatori (Sutajaya, 2006). Dengan demikian pembelajaran melalui pendekatan SHIP diharapkan dapat meningkatkan kualitas kesehatan pebelajar dan luaran proses belajarnya. 
Dalam pendekatan SHIP
ditekankan bahwa masalah harus
dipecahkan secara: (a) sistemik atau
melalui pendekatan sistem, dimana
semua faktor yang berada di dalam satu
sistem dan diperkirakan dapat menimbulkan masalah harus ikut diperhitungkan sehingga tidak ada lagi masalah yang tertinggal atau munculnya masalah baru sebagai akibat dari keterkaitan sistem; (b) holistik artinya semua faktor atau sistem yang terkait atau diperkirakan terkait dengan masalah yang ada, haruslah dipecahkan secara proaktif dan menyeluruh; (c) interdisipliner artinya semua disiplin terkait harus dimanfaatkan, karena makin kompleksnya permasalahan yang ada diasumsikan tidak akan terpecahkan secara maksimal jika hanya dikaji melalui satu disiplin, sehingga perlu dilakukan pengkajian melalui lintas disiplin ilmu; dan (d) partisipatori artinya semua orang yang terlibat dalam pemecahan masalah tersebut harus dilibatkan sejak awal secara maksimal agar dapat diwujudkan mekanisme kerja yang kondusif dan diperoleh produk yang berkualitas sesuai dengan tuntutan jaman (Sutajaya, 2006). Dengan demikian pendekatan SHIP dapat diartikan sebagai upaya pemberdayaan seseorang agar lebih terbuka, transparan, delegatif, kolaboratif, dapat menghargai perbedaan, dapat menghargai manajemen waktu dan konflik, mampu bekerja dalam tim, mampu mengurangi arogansi, tidak memonopoli waktu, dan sadar akan demokrasi dan hak-hak asasi manusia (Manuaba, 2004a). Konsekuensinya adalah melalui pendekatan SHIP dapat diseimbangkan antara tuntutan tugas (beban kerja) dan kapasitas (kemampuan, kebolehan dan keterbatasan) manusia sehingga mereka dapat bekerja secara efektif, nyaman, aman, sehat dan efisien serta tercapai produktivitas yang setinggitingginya (Manuaba, 2004a).

Langkah-langkah dalam pembelajaran melalui pendekatan SHIP adalah: (1) dibentuk tiga kelompok diskusi yang dilakukan dengan cara undian sehingga masing-masing kelompok terdiri dari 5 - 6 orang peserta ditambah satu orang fasilitator; (2) pada setiap awal pembelajaran untuk setiap pokok bahasan dilakukan brainstorming yang dipandu oleh seorang fasilitator dan ditulis di kertas kecil serta ditempel di papan tulis atau tembok dimana hasil kerja ini akan dinilai oleh fasilitator dan pengajar yang sekaligus bertindak sebagai moderator; (3) siswa berkeliling mencermati hasil kerja kelompok lain yang dipandu oleh fasilitator; (4) siswa membuat lis permasalahan yang mengacu kepada hasil brainstorming pada kegiatan I dan ditulis di kertas besar lalu ditempel di papan tulis atau tembok dan dipresentasikan serta dinilai oleh fasilitator dan moderator; (5) siswa menjawab setiap masalah yang dibuat oleh kelompok lain dan jawaban tersebut ditempel di sebelah lis permasalahan yang dijawab serta dinilai oleh fasilitator dan moderator; (6) setiap kelompok membuat simpulan atau ringkasan untuk masing-masing jawaban kelompok lain dan dipadukan dengan jawaban dari kelompoknya sendiri serta dikaitkan dengan tujuan pembelajaran khusus pada buku ajar, dimana hasil kerja tersebut dinilai oleh fasilitator dan moderator. Pengetahuan guru mengenai pendekatan SHIP ini 
dapat digunakan sebagai penambah wawasan dalam penerapan pembelajaran inovatif.

Kendala yang sering dijumpai terkait dengan upaya sosialisasi ergonomi dalam pembelajaran guna meningkatkan profesionalisme guru adalah: (1) belum diketahui, dipahami dan dimengertinya tentang kaidahkaidah ergonomi yang dapat dimanfaatkan sebagai acuan atau standar dalam mendesain sarana dan prasarana serta proses pembelajaran; (2) jika kaidah ergonomi sudah diketahui, namun karena lebih mementingkan metode tertentu dalam pembelajaran maka standar yang berlaku dalam ergonomi sering diabaikan atau dinomorduakan; (3) belum diketahui akibat yang akan timbul jika sarana dan prasarana serta metode pembelajaran tidak sesuai dengan kaidah ergonomi sehingga dalam proses pembelajaran tidak mempertimbangkan kemampuan, kebolehan, dan batasan fisik pebelajar; (4) ada pengajar yang agak arogan dan menganggap apa yang diterapkannya dalam proses pembelajaran sudah baik dan benar, padahal mereka belum memasukkan unsur-unsur ergonomi atau belum mengacu kepada respon fisiologis pada organ yang akan menerima dampak negatif dari proses pembelajaran yang berkepanjangan yang disertai dengan sarana dan prasarana yang tidak ergonomis; (5) karena pertimbangan ekonomi, alokasi waktu, dan biaya yang harus dikeluarkan untuk mendesain ruang belajar yang ergonomic, mengakibatkan acuan ergonomi sering diabaikan karena ada anggapan bahwa jika memasukkan kaidah ergonomi maka biayanya akan membengkak; dan
(6) penerapan ergonomi dalam pembelajaran yang membutuhkan guru inovatif, proaktif, dan produktif sering tidak tersedia di suatu sekolah sehingga prinsip-prinsip ergonomi yang sangat aplikatif tetap dalam batas wacana.

\section{SIMPULAN DAN SARAN}

Dari hasil kajian tersebut dapat disimpulkan sebagai berikut. (1) Pengetahuan guru mengenai prinsipprinsip ergonomi dalam pembelajaran sangat relevan di dalam upaya meningkatkan profesionalisme guru; (2) Pemahaman guru mengenai peranan prinsip-prinsip ergonomi dalam pembelajaran dan dampak yang ditimbulkan oleh sarana dan prasarana yang tidak ergonomik dapat menambah wawasannya dalam upaya pengelolaan kelas; dan (3) Kendala yang dihadapi dalam mensosialisasikan prinsip-prinsip ergonomi dalam pembelajaran dapat dijadikan tantangan sekaligus peluang dalam penerapan ergonomi di sekolah.

Saran yang tampaknya penting untuk disampaikan pada kajian ini adalah: (1) dalam mendesain atau meredesain ruang belajar, disarankan untuk selalu menerapkan kaidah-kaidah ergonomi; (2) kaidah-kaidah ergonomi harus diterapkan sejak dini, sehingga tidak memerlukan biaya yang besar atau tidak ada biaya yang terbuang percuma yang hanya dapat dilakukan oleh guru yang inovatif, proaktif, dan produktif; dan (3) profesionalisme guru hendaknya dilengkapi dengan kompetensi dalam bidang ergonomi sehingga mereka mampu mengelola kelas secara efektif, nyaman, aman, sehat, dan efesien.

\section{DAFTAR PUSTAKA}

Antari, N. N. M. (2004). Penggunaan 
one way screen dalam ruang pelatihan mikro konseling dapat menurunkan beban kerja dan tingkat kecemasan pada mahasiswa calon konselor jurusan bimbingan konseling IKIP Negeri Singaraja. Program Pascasarjana Universitas Udayana.

Dul, J., \& Weerdmeester, B. (2003). Ergonomics for beginners: a quick reference guide. CRC press.

Gamez, L., \& Cybis, W. A. (1998). An Ergonomic Approach to Educational Software Evaluation. Scott, PA; Bridger, RS; Chartevis, J. Global Ergonomic. Amsterdam: Elsevier, 601-605.

Grandjean, E. (1988). Fitting the task to the Man. A Texbook of Occupational Ergonomics. Taylor \& Francis. London.

Helander, M. G., \& Shuan, L. (2005). Reducing Design Complexxity Will Improve Usability in Product Design. In Proceeding of Seaes IPS Conference (pp. 23-25).

Iridiastadi, H. (2014). Ergonomi suatu pengantar. Ergonomi Suatu Pengantar.

Manuaba, A. (2003a). Optimalisasi Aplikasi Ergonomi dan Fisiologi Olahraga dalam Rangka Peningkatan Produktivitas Tenaga Kerja dan Prestasi Atlet. In Makalah. Disampaikan pada seminar Nasional Ergonomi dan Olahraga di Universitas Negeri Semarang (Vol. 12).

Manuaba, A. (2003b). Total ergonomic approach to enhance and harmonize the development of agriculture, tourism, and small scale industry, with special reference to Bali. In National
Congress and Seminar of the Indonesian Ergonomics Association (PEI) (Vol. 13).

Manuaba, A. (2004a). Kontribusi Ergonomi dalam Pembangunan, dengan Acuan Khusus Bali. In 2nd National Seminar on Ergonomics, UGM, Yogyakarta (Vol. 9).

Manuaba, A. (2004b). Membangun Desa Tanaman Hias Petiga melalui Tiga Sektor Potensial Ekonomi Bali Secara Harmoni dalam Rangka Pembangunan Bali Berlanjut. Makalah.

Nala, N. (1994). Penerapan Teknologi Tepat Guna di Pedesaan. Denpasar: Lembaga Pengabdian Kepada Masyarakat Universitas Udayana.

Olszewski, J. (1998). Ergonomics for Work System Creating. Scott, $P A$; Bridger, RS; Chartevis, J. Global Ergonomic. Amsterdam: Elsevier, 449-451.

Partadjaja, T. R. (2004). Aplikasi Program Kesehatan Sekolah (UKS) melalui Perbaikan Sistem Pencahayaan dan Pengembangan Media Pembelajaran Matematika terhadap Ketelitian, Kecepatan Kerja dan Konstansi Siswa di Kelas $V$ SD 1 dan SD 2 Guwang Sukawati Gianyar. Tesis.

Pasiak, H. T., \& Others. (2007). Brain Management for Self Improvement. Mizan Pustaka.

Sutajaya, I. M. (2001). Ergonomic Participatory Approach in Teaching-Learning Model of Human Anatomy and Physiology Used Teaching Material Suplement Based on Science and Technology Society Approach in Biologi Study Program STKIP Singaraja. Laporan 
Penelitian.

Sutajaya, I. M. (2006). Pembelajaran Melalui Pendekatan Sistemik Holistik Interdisipliner dan Partisipatori (SHIP) Mengurangi Kelelahan, Keluhan Muskuloskeletal, dan Kebosanan serta Meningkatkan Luaran Proses Belajar Mahasiswa Biologi IKIP Singaraja. Disertasi. Denpasar: Program Pascasarjana Universitas Udayana.

Sutajaya, I. M., \& Citrawathi, D. M. (2001). Perbaikan Kondisi Kerja Mengurangi Beban Kerja dan Gangguan pada Sistem Muskuloskeletal Mahasiswa dalam Menggunakan Mikroskop di Laboratorium Biologi STKIP Singaraja. Majalah Kedokteran Udayana (Udayana Medical Journal), 32(114).

Sutjana, I. D. P., Sutajaya, I. M., Tunas,
K., \& Suardana, I. (2004). Penerapan Model Pembelajaran Fisiologi Berbasis Sains-TeknologiMasyarakat (STM) Mengacu Materi Ergonomi Meningkatkan Hasil Belajar dan Peran Aktif Mahasiswa Fakultas Kedokteran Universitas Udayana. Makalah. Denpasar: Fakultas Kedokteran Universitas Udayana.

Velasco, A. L. (2002). Value Engineering as An Ergonomics Tool to Measure Benefits of Ergonomic Interventions. Jurnal Ergonomi Indonesia (The Indonesian Journal of Ergonomics), 3(2), 12.

Wignjosoebroto, S. (2000). Evaluasi Ergonomis Dalam Proses Perancangan Produk. In Surabaya: Proceeding Seminar Nasional Ergonomi, Jurusan TI--ITS. 